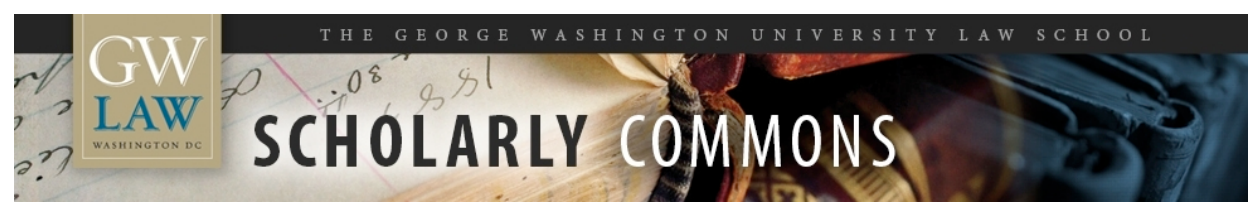

\title{
FALSE CLAIMS ACT: Greater DOJ Scrutiny of Frivolous Qui Tam Actions?
}

Steven L. Schooner

George Washington University Law School, sschooner@law.gwu.edu

Follow this and additional works at: https://scholarship.law.gwu.edu/faculty_publications

Part of the Law Commons

\section{Recommended Citation}

Schooner, Steven L., FALSE CLAIMS ACT: Greater DOJ Scrutiny of Frivolous Qui Tam Actions? (April 2018). Steven L. Schooner, False Claims Act: Greater DOJ Scrutiny of Frivolous Qui Tam Actions?, 32 NASH \& CIBINIC REP. 920 (2018). ; GWU Law School Public Law Research Paper No. 2018-12; GWU Legal Studies Research Paper No. 2018-12. Available at SSRN: https://ssrn.com/abstract=3152097

This Article is brought to you for free and open access by the Faculty Scholarship at Scholarly Commons. It has been accepted for inclusion in GW Law Faculty Publications \& Other Works by an authorized administrator of Scholarly Commons. For more information, please contact spagel@law.gwu.edu. 
This material from THE NASH \& CIBINIC REPORT has been reproduced with the permission of the publisher, Thomson Reuters. Further use without the permission of the publisher is prohibited. For additional information or to subscribe, call 1-800-344-5009 or visit http://legalsolutions.thomsonreuters.com. THE NASH \& CIBINIC REPORT is now available on Westlaw. Visit westlaw.com.
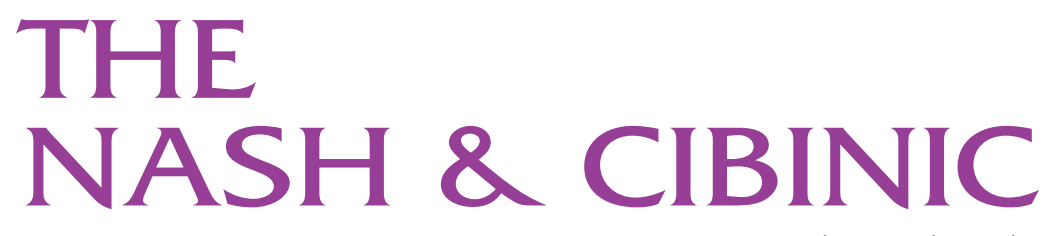

REPORT $\begin{aligned} & \text { government contract analysis and advice monthly from } \\ & \text { professors ralph c. nash and john cibinic }\end{aligned}$

Author: Ralph C. Nash, Professor Emeritus of Law, The George Washington University

Contributing Authors: Vernon J. Edwards and Steven L. Schooner

\section{APRIL 2018 | VOLUME 32 | ISSUE 4}

\section{PUBLIC POLICIES}

\section{20 FALSE CLAIMS ACT: Greater DOJ Scrutiny Of Frivolous Qui Tam Actions?}

Steven L. Schooner

The U.S. Department of Justice's Civil Division recently circulated new guidance for its attorneys handling False Claims Act cases. See Memorandum from Michael D. Granston, Director, Commercial Litigation Branch, Fraud Section, "Factors for Evaluating Dismissal Pursuant to 31 U.S.C. § 3730(c)(2)(A)" (Jan. 10, 2018), available at https://assets.documentcloud.org/d ocuments/4358602/Memo-for-Evaluating-Dismissal-Pursuant-to-31-U-S.pdf. In what many perceive as a radical or, at very least, dramatic change in policy and practice, the memorandum recommends that, "when evaluating a recommendation to decline intervention in a qui tam action, attorneys should also consider whether the government's interests are served. . .by seeking dismissal pursuant to 31 U.S.C. $§ 3730(c)(2)(A)$." [Emphasis added.] This looks like a bold and important step in the right direction, although we fear it may only amount to a baby step or, even worse, guidance generally ignored by DOJ attorneys.

\section{The DOJ's FCA Options}

When a qui tam relator-acting, in effect, as a whistleblower or a private attorney general—files an FCA suit under seal in a federal court, the DOJ has a statutory duty to take one of four actions (not counting the commonly exercised right to seek an extension of time to make a determination, 31 USCA § 3730(b)(3)):

(1) proceed with the action, in which case the action — the prosecution or litigation of the civil false claim —is conducted by the Government, 31 USCA $\S 3730(b)(4)(A) ;$

(2) decline to take over the action, in which case the relator enjoys the right to conduct the action (on the Government's behalf), 31 USCA $\S 3730(b)(4)(B)$;

(3) settle the action, even over the relator's objection (assuming "the court determines. . .that the proposed settlement is fair, adequate, and reasonable"), 31 USCA $\S 3730(\mathrm{c})(2)(\mathrm{B})$; or 
(4) dismiss the action, even over the relator's objection (giving notice to the relator and after the court provides the relator with an opportunity for a hearing), 31 USCA $\S 3730(c)(2)(A)$.

And therein lies the rub. Decades of experience informs us that the DOJ cherry picks the best—or most attractive-cases with which to proceed based upon its internal calculus. In choosing among the options indicated above, the DOJ takes into account, among other things, the strength of the relator's allegations (and, thus the likelihood of success on the merits), the potential for recovery (yes, Virginia, the DOJ is interested in larger civil fraud recoveries), and, of course, its litigation resources (because you can't do everything). Once the DOJ elects to proceed, most of those cases settle and, even though some are fully litigated, the culling process results in the DOJ boasting an extraordinarily high success and recovery rate for these cases.

At the opposite end of the spectrum, chaos and inefficiency reign. Historically, the DOJ rarely dismisses actions-the DOJ memorandum uses the word "sparingly." Dismissals are so rare_approaching zero, statistically speaking — that they enjoy a form of unicorn status. See, e.g., Kovacic, Whistleblower Bounty Lawsuits as Monitoring Devices in Government Contracting, 29 Loy. L.A. L. Rev. 1799, 1818 (1996) (From 1986 to 1996, the DOJ appeared to seek dismissal of a qui tam suits only where it found jurisdictional flaws. Specifically, Kovacic found "only a single reported instance in which the DOJ has sought to dismiss a qui tam suit on the ground that the suit lacked substantive merit or otherwise contradicted the interests of the United States."). While the DOJ has been less than transparent on the numbers, subsequent efforts to study the data have suggested that the DOJ affirmatively moves to dismiss less than $1 \%$ of the qui tam actions filed each year.

The remaining matters, the ones in which the DOJ has declined to take action, are a messy lot. That makes sense given that, for cases in which the DOJ declines to intervene, the statute permits the same qui tam relators that failed to impress DOJ's attorneys to drive the litigation train. Relators rarely hit the jackpot (although there have been isolated exceptions), and many of these cases settle for nominal sums. Private sector defendants, on the other hand, spend staggering sums defending these actions.

\section{The Government's Interest: Economic Efficiency And Precedent}

The best news is that the DOJ appears to have acknowledged, in a rather formal document, that Government line attorneys have more than a pro forma, if not an affirmative, duty to consider moving to dismiss frivolous qui tam suits. Time will tell if the memorandum leads to more concrete outcomes.

Readers may wonder why the DOJ's leadership raised the issue early in 2018 (or, on October 30, 2017, when Director Granston appears to have first publicly floated the idea at conference), rather than addressing the private sector's experience over the last three decades. The DOJ clarified that the new approach was driven by "record increases in qui tam actions filed [over the last several years],. . .with annual totals approaching or exceeding 600 new matters." While the DOJ's "rate of intervention has remained relatively static," the large incoming docket apparently concerned the DOJ for two Governmentcentric reasons, neither, apparently, related to unfair harm to or excessive burden upon defendants. First, even when the DOJ chooses not to intervene, the DOJ assumes "monitoring" burdens and "sometimes must produce discovery or otherwise participate." Second, and unsurprisingly, cases that the DOJ deemed lacking in "substantial merit. . .can generate adverse decisions that affect the government's ability to enforce the FCA."

That Government-centric analysis is disappointing. We would have liked to see the DOJ more explicitly acknowledge that, in fulfilling its statutory mandate, the DOJ also serves the public interest by weeding out and dismissing frivolous matters. Yes, Granston's memorandum specifically acknowledges that the DOJ "plays an important gatekeeper role. . ., because in qui tam cases where we decline to intervene, the relators largely stand in the shoes of the Attorney General. That is why the FCA provides [the DOJ] with the authority to dismiss cases." But Granston seemed unwilling to concede-at least in this internal memorandum - that the DOJ also should perform an important, congressionally mandated public service by assisting the private sector in avoiding significant costs, reputational harms, and, of course, the nonproductive distractions associated with litigating suits once the DOJ has found those suits lacking in merit. Alerting the court, and encouraging the courts to dismiss cases that lack substantial merit-either completely or in part-seems like an appropriate gatekeeper function, particularly in light of the statutory rubric that Congress originally created and that the DOJ appears to acknowledge in footnote 2 , where it 
summarizes the congressionally articulated "mechanisms contained in the FCA to ensure that the United States retains substantial control over lawsuits brought on its behalf."

\section{Useful Insights From The DOJ}

Regardless, the memorandum's primary purpose is to provide a new rubric or menu of factors that DOJ attorneys should consider in deciding whether to dismiss cases. Apparently, these seven factors were derived from a review of "those cases in which the Government moved to dismiss relators pursuant to this statutory provision since 1986, when the provision was added to the FCA." We were not surprised that, even after more than 30 years, the universe of such cases remains small (and, indeed, the word "paltry" comes to mind). Nonetheless, any such exhaustive summary of DOJ advocacy and federal court jurisprudence created and "published" by the DOJ is noteworthy in and of itself.

Disclaimer: Astute N\&CR readers will no doubt notice that the memorandum at issue here is labeled: "Privileged and Confidential; For Internal Government Use Only." The NATIOnal LaW Journal originally republished (or, as some suggest, leaked) the internal memorandum on its website, and the memorandum promptly gained wide distribution. For better or worse, it's in the public domain now. Of course, public disclosure does not change the nature or purpose of the memorandum, and we do not encourage counsel to cite to the memorandum in their federal court filings. It is not a regulation previously subject to notice-and-comment rulemaking, nor will you find it in 28 CFR Chapter I. It remains what it was issued as—internal guidance intended for Government (specifically DOJ) attorneys. But that doesn't make it any less informative.

\section{The Factors}

The memorandum clarifies that the list of factors is neither exclusive (e.g., attorneys may wish to consider dismissing relator actions for other reasons) nor mutually exclusive (e.g., attorneys may wish to consider dismissing relator actions for more than one of these reasons). In addition to listing the seven factors, the memorandum references prior cases in which the various factors have been relied upon. The seven factors are:

(1) Curbing Meritless Claims - This includes those cases in which the relator's "complaint is facially lacking in meriteither because relator's legal theory is inherently defective, or the relator's factual allegations are frivolous." For the contractor bar, this may be the most disappointing passage in the memorandum. Granston scored maximum points for transparency in explaining that, in order "to maximize its resources[,] the government typically will investigate a qui tam action only to the point where it concludes that a declination is warranted. This may not equate to a conclusion that no fraud occurred." In other words, the DOJ only keeps digging until it determines—-for whatever reason—-that it's not "worth it" for the DOJ to intervene. The defendants' lot is not the DOJ's concern.

(2) Preventing Parasitic or Opportunistic Qui Tam Actions-These are matters "that duplicate[] a pre-existing government investigation and add[] no useful information to the investigation." Specifically, the DOJ cautions that, in these cases, "the government should consider whether the relator would receive an unwarranted windfall at the expense of the public fisc because" Congress did not mean to incentivize relators to provide "information already known to the government."

(3) Preventing Interference With Agency Policies and Programs-This seemed like a small universe of cases, but, arguably, one of the most obvious areas in which we would expect the DOJ to serve a gatekeeping function. The examples confirmed that these are unique situations, See, e.g., U.S. ex rel. Ridenour v. Kaiser-Hill Co., LLC, 397 F.3d 925 (10th Cir. 2005), where, as the memorandum explains, the DOJ "successfully moved to dismiss the action because. . .litigation would delay the clean-up and closure of the [Rocky Flats] facility by diverting agency personnel and resources away from the project." We do not see this factor finding broad application.

(4) Controlling Litigation Brought on Behalf of the United States-These matters should be dismissed "when necessary to protect the Department's litigation prerogatives." This again seems to be a common sense application of the gatekeeping function. For that reason, we were surprised by the small, and frankly, unimpressive number of examples that the DOJ referenced: (1) multidistrict litigation involving natural gas royalties; (2) a pending Federal Torts Claims Act case against the same parties; and (3) a matter "that was serving as an obstacle to the settlement of the government's intervened claims." 
Equally perplexing was that the DOJ conceded, in footnote 3, that, in each of these cases, the DOJ also "had determined that the claims lacked substantial merit," thus implying that the matters should have been dismissed for other, more obvious reasons.

(5) Safeguarding Classified Information and National Security Interests-Our sense is that this consideration, typically applied to matters "involving intelligence agencies or military procurement contracts," is rather straightforward and speaks for itself.

(6) Preserving Government Resources - The DOJ suggests that dismissal may be appropriate where "the government's expected costs are likely to exceed any expected gain." As noted above, these costs include "the need to monitor or participate in ongoing litigation, including responding to discovery requests." The DOJ further elaborates, in footnote 4 , that this calculus "includes the opportunity cost of expending resources on other matters with a higher and/or more certain recovery." Again, to be clear, only the Government's resources are considered.

(7) Addressing Egregious Procedural Errors-This rather limited exception covers matters in which the relator's actions (or egregious procedural errors) "frustrate the government's efforts to conduct a proper investigation" of the allegations or claims upon which the suit is based. Compared to the other factors, this appears to provide thin gruel for future application. For an interesting recent pro se analogy (an albeit imperfect analogy, or possibly a case study, in why it's worth hiring an attorney), see King v. U.S. Government, 878 F.3d 1265 (11th Cir. 2018).

\section{Nothing In Life Is Incredibly Simple}

The memorandum reminds us why the DOJ seeks to dismiss so few cases in which it chooses not to intervene. Quite simply, seeking dismissal requires more work. The memorandum reminds attorneys of the need to coordinate and "consult closely" with agency counsel in seeking dismissal. It also cautions that earlier is better: "if one waits until the close of discovery or trial, there is a risk that the court may be less receptive to the request given the expenditure of resources by the court and parties." The memorandum also reminds DOJ attorneys that the "prudent course" is not to take these motions to dismiss for granted. While some courts (e.g., the U.S. Court of Appeals for the District of Columbia Circuit) apply an "unfettered" discretion test to the DOJ's 31 USCA $\S 3730(\mathrm{c})(2)(A)$ dismissal motions, other courts (e.g., the 9th and 10th Circuits) apply a "rational basis" test. See, e.g., Swift v. U.S., 318 F.3d 250, 252 (D.C. Cir. 2003); U.S. ex rel. Sequoia Orange Co. v. Baird-Neece Packing Corp., 151 F.3d 1139, 1147 (9th Cir.1998); U.S. ex rel. Wickliffe v. EMC Corp., 473 Fed. Appx. 849, 852 (10th Cir. 2012). In other words, moving to dismiss a relator's qui tam action isn't a task undertaken lightly. So, if you're a busy DOJ litigator, why bother? What's in it for you? Better to simply decline intervention and turn your attention to other matters.

\section{Ending On A Sour Note}

To that end, the memorandum closes by reinforcing the perverse logic that leads many DOJ attorneys to hold their noses, turn the other cheek, and avoid wasting effort moving to dismiss once they've decided not to intervene. Buried at the end of the memorandum, in footnote 5, is the extraordinary statistic: "Since January 1, 2012, more than 700 qui tam actions have been dismissed by relators after the government elected not to intervene." In other words, the DOJ's recent experience demonstrates that, on average, more than 115 relators walk away each year if the DOJ decides not to take over their cases. For that reason, the DOJ recommends that its attorneys "advis[e] relators of perceived deficiencies in their cases...so that [they] make an informed decision regarding whether to proceed." The subtle message resonates: if you're unwilling to do the right thing and put an end to relator's unpersuasive suit, the least you can do-before you saddle the defendant with enormous and unproductive legal defense costs-is tell the relator (and plaintiff's counsel) that they're probably wasting their time and money. We agree: that's better than doing nothing.

\section{Moral Hazard: Gatekeeper For Whose Interests?}

Still, we would have liked to see Granston and the DOJ go further. Despite a statutory mandate that the DOJ, through the attorney general "diligently shall investigate" potential FCA violations (31 USCA $\S 3730(a)$ ), a steady stream of research suggest that the DOJ's unwillingness_-for whatever reason (political, economic, resource limitations, etc.) — to meaningfully perform its gatekeeping function places an enormous, inefficient burden on companies forced to defend qui tam suits that the 
DOJ has previously deemed unworthy of its time, effort, energy, or resources. See generally Kirchmaier, Treating the Symptoms But Not the Disease: A Call To Reform False Claims Act Enforcement, 209 MrL. L. Rev. 186 (2011) (advocating that "the government should also accept greater responsibility for ensuring FCA enforcement is limited only to those suits that have some veritable basis for being prosecuted on the government's behalf"). Kirchmaier noted that the DOJ's "FCA statistical data suggests that roughly 8 out of 10 qui tam lawsuits could be affirmatively dismissed instead of being outsourced for private prosecution." We agree with Kirchmaier that "[a]llowing relators to litigate qui tam actions that have limited chances of success in the courts produces few discernible public benefits and generates unrecorded costs to the public fisc."

Kirchmaier isn't alone, and critiques of the DOJ's laissez faire de facto delegation of its congressionally assigned prosecutorial discretion to the plaintiff's bar are neither new nor novel. See, e.g., Kwok, Evidence From the False Claims Act: Does Private Enforcement Attract Excessive Litigation?, 42 Puв. Cont. L.J. 225, 237 (2013) ("DoJ's published data demonstrate that relators and their law firms do not have a good track record in successfully litigating nonintervened cases."); Rich, Prosecutorial Indiscretion: Encouraging the Department of Justice To Rein in Out-of-Control Qui Tam Litigation Under the Civil False Claims Act, 76 U. Cin. L. Rev. 1233, 1264 (2008) (finding that fewer than 10\% of qui tam cases in which the Government chooses not to intervene result in a monetary recovery to either the relator or the Government); Matthew, The Moral Hazard Problem With Privatization of Public Enforcement: The Case of Pharmaceutical Fraud, 40 U. Mich. J.L. Reform 281 (2007) (when the Government does not intervene, "the qui tam relator does not have the ethical obligation to protect the interests of the public at large. . . [and] has neither an ethical nor financial interest compelling it to consider the impact of frivolously imposing defense costs on target companies"); Broderick, Note, Qui Tam Provisions and the Public Interest: An Empirical Analysis, 107 Colum. L. Rev. 949, 975 (2007) (between 1987 and 2004, nearly three-quarters of all qui tam actions in which the DOJ did not intervene were ultimately dismissed); Rabkin, The Secret Life of the Private Attorney General, 61 L. \& Contemp. Probs. 179, 198, 203 (1998) (“[T]he law. . .actually imposes a series of procedural hurdles that may discourage the government from halting the case. . .. The private attorney general . . . can often be a considerable convenience for Congress, a device to delegate policy initiative without taking full responsibility for the consequences."); Kovacic, Whistleblower Bounty Lawsuits, supra.

We think Rich gave the DOJ the benefit of the doubt when he concluded that the primary reason the DOJ hesitated to dismiss relators' suits was hope- that one-in-a-hundred chance that the relator's litigation would lead to a significant monetary recovery. Our sense is that the more powerful forces that drive inaction are (1) lack of resources, (2) lack of incentives for line attorneys to gain approval for, draft, and argue a dismiss motion, and (3) fear of congressional or media criticism. Sadly, we are most sympathetic to the latter, and we also fear it is the most intractable. To the extent that a disappointed relator can tell his or her best story to a member of Congress or a reporter, in our experience, the DOJ's public relations office is unlikely to offer a fulsome explanation in defense of a successful motion to dismiss.

\section{An Avoidable Moral Hazard}

More broadly, we think that Matthew summed the problem up nicely as a moral hazard:

The Government imagines it has nothing to lose even if these cases fail because all immediate costs of failed cases under the FCA are borne by the private plaintiff. Thus, in the face of weak monitoring incentives, the Government will allow cases based on weak facts or even unfounded or experimental theories of recovery to proceed. Nothing is immediately lost to the Government for this carelessness.

In other words, as noted above, the private sector defendants don't factor into the Government's analytical rubric.

Of course, our readers are familiar with our concerns that there are too many qui tam suits that find their way into the federal court system even after the DOJ has determined that the cases lack merit, particularly when those cases are based on mistakes in business judgment as opposed to true misconduct. See An Efficient Procurement System: Striking a Balance Between Freedom and Accountability, $9 \mathrm{N \& CR}$ II 30. The litigation costs borne by contractors in these matters are not negligible, nor is the cost allowability issue clear or easily resolved. See, e.g., FAR 31.205-47(b), (c)(2); Qui Tam Settlements and "Proceedings" Costs, 13 N\&CR II 22; Qui Tam "Proceedings" Costs: Clarification or Change?, 13 N\&CR II 4. Thus, there are strong disincentives to litigate — even with an eye towards a successful defense and a recovery of attorney's fees—when a nuisance settlement will far more expeditiously conclude a frivolous piece of litigation. See Litigation Costs: Employee Allegations of 
Improper Conduct, 11 N\&CR II 53, citing Fraud, Forfeiture, and Collateral Estoppel, 11 N\&CR II 46. See also Briggerman, Allowability of Legal Cost: Settlement of Third-Party Litigation, 23 N\&CR II 50 ("[U]p to a point it makes sense to say that if a third-party lawsuit that 'relates' to some underlying fraudulent activity is settled, the costs of that litigation should be unallowable unless the contractor can demonstrate the suit had 'very little likelihood of success on the merits.' " But, in practice, demonstrating "very little likelihood of success on the merits" is no mean feat).

\section{Our Take: Reason For Optimism Or Much Ado About Nothing?}

All of which is why we'll join the chorus that applauds the memorandum for-if nothing else-moving the needle in the right direction. Applying the "it's better than nothing" and the "we're no worse off than we were before" tests, there is the distinct possibility that some line attorneys across the country will take the headquarters guidance to heart. If, going forward, the DOJ pulls the plug on any appreciable number of frivolous qui tam matters, that would offer a welcome respite for contractors and the health care industry.

The plaintiffs' bar appears split on the memorandum's significance. While some may privately fear that their cases will be prematurely derailed, we have yet to see an attorney publicly bemoan the DOJ's efforts to rein in his or her ability to bring unsubstantiated, half-baked, unpersuasive fishing expeditions. (Sarcasm aside, we assume that relator's counsel typically perceive their suits' allegations as both substantive and persuasive, just as we expect that few members of the qui tam bar selfidentify as stereotypical bounty hunters.)

On the defense side-where, increasingly, health care related claims (including, of course, claims against pharmaceutical firms and the medical device manufacturing community) dwarf defense contractor complaints-we expect the private bar to take the memorandum at face value and hope for the best. Given the stakes, counsel would be well advised to more aggressively pursue, or at least experiment with, a "decline and move to dismiss" approach in dealing with Government counsel. At least in the short term, we also expect defense counsel to embrace the memorandum's seven-step rubric as the research outline of choice for papers, Power Point presentations, and other declination-related advocacy directed at DOJ attorneys. Counsel should also consider relying on and emphasizing the (admittedly small) number of cases that the DOJ identified as the most compelling precedent supporting each of the seven factors.

Only time will tell whether the rubric — or any of its content—actually proves useful to defense counsel seeking to persuade the Government to move to dismiss a relator's qui tam case. Analogizing to the familiar cooperation between agency counsel and intervenors in bid protest litigation, we could envision the Government contracts bar ultimately offering more sophisticated assistance, suggestions, and even draft language to DOJ counsel to entice him or her to move to dismiss, rather than simply taking the least strenuous option of declining to intervene, when faced with a frivolous qui tam action. Hope springs eternal. SLS 